\title{
LIDSKÁ PRÁVA - OD HISTORIE DO SOUČASNOSTI
} 1. Znalost lidských práv jako předpoklad je-
jich prosazování

Každý se ve svém životě s pojmem „lidská práva“ či „základní svobody“ už jistě setkal. Téma lidských práv je velmi frekventované, zároveň také velmi citlivé, veřejností pozorně sledované. Je to dáno jednak samotným předmětem úpravy a okruhem adresátů (tj. člověk, lidská bytost), jednak možnostmi, které nabízí moderní prostředky komunikace a přenosu informací na velké vzdálenosti, ještě nedávno těžko představitelné. Široké vrstvy obyvatelstva po celém světě se tak mohou poměrně jednoduchým způsobem, prostřednictvím sdělovacích prostředků nebo např. kampaní vlád či různých nevládních organizací, dozvědět mnohé o lidských právech, jejich obsahu, významu, ochraně a snahách omezit jejich porušování v jednotlivých státech. Přesto jsme však svědky každodenního, mnohdy závažného porušování základních lidských práv, např. v souvislosti s ozbrojenými konflikty. Úsilí o osvětu ohledně lidských práv by proto nemělo polevovat, protože pouze ten, kdo zná svá práva, může prosazovat jejich dodržování a ochranu.

\section{Vznik a vývoj lidských práv}

Lidská práva jsou úzce spojena s historií lidského rodu a provází jej od samého počátku jeho bytí. Jejich kořeny sahají hluboko do minulých staletí lidské existence a souvisí s vývojem státu i společnosti samé. Cesta rozvoje lidských práv byla dlouhá a nelehká, formována četnými vlivy zejména náboženskými, sociálními, etnickými či kulturními. Se zárodky lidských práv se lze setkat již v sumerských a babylonských městských státech (4. - 3. tisíciletí př. Kr.), v antickém Řecku (již od r. 2000 př. Kr.) či Rímě (r. 753 př. Kr. - r. 486 po Kr.), v křest'anských i židovských pramenech, které pak dále významně ovlivnily vývoj na evropském kontinentě (Spolek Juristic, 2000). Např. Putz se ve svém díle „Křest'anství a lidská práva“ snaží sledovat, jak lidská práva vykrystalizovala ve spisech Starého a Nového zákona, v právním systému Izraelitů a ve filozofické tradici. Především z Nového zákona vyplývá koncepce lidské
7: 1-200, 2005 ISSN $1212-4117$ důstojnosti (Putz, 1992). Také zásady obsažené v biblickém Desateru v sobě nesou mj. poselství úcty a respektu k osobnosti člověka, $\mathrm{k}$ jeho životu, majetku a tím vlastně i zárodek lidských práv v té podobě, jak se postupně vyvinula a jak ji známe dnes. V díle Tomáše Akvinského (1225-1274) (Jehlička-Švestka et al., 1994) pak lze nalézt již zcela konkrétní myšlenky o právu na život, na vlastnictví a práci, na spravedlivý soudní proces apod. (Putz, 1992) .

Zlomové období pro genezi lidských práv znamenal příchod novověku spojený s nástupem nových směrů $\mathrm{v}$ politice, ekonomice, filozofii, $\mathrm{kdy}$ se ideje lidských práv a snahy o jejich zakotvení do písemné formy začaly uplatňovat $\mathrm{v}$ mnohem větši míře. Významní myslitelé, jako např. Thomas Hobbes (1588-1679) v Leviathanu nebo John Locke (1632-1704, považovaný za otce osvícenstvî) ve svém díle Druhé pojednání o vládě, vycházejí z tzv. koncepce přirozených práv člověka, prričemž za základní přirozené právo člověka považují právo na život. (Coreth a Schöndorf 2002, Přibáñ 1996) Jean Jacques Rousseau (1712-1778) se ve svém díle $O$ společenské smlouvě zase zabývá otázkou rovnosti, „...bez níž není svobody“ a kritizuje Hobbese a Grotia za jejich popírání rovnosti mezi lidmi (Př́báń, 1996). V tomto období se prosazuje tzv. individualistické pojetí lidských práv, tedy že práva svědčí konkrétnímu jedinci, autonomnímu individuu. Práva člověka již nevyplývají $\mathrm{z}$ př́ślušnosti $\mathrm{k}$ nějaké společenské skupině, nejsou odvozena od vztahu $\mathrm{k}$ bohu; jsou založena prostě na tom, že je člověkem. (Amnesty International) Idea lidských práv se do právních rádů jednotlivých států dostává v míře podstatné až ve 2 . polovině 18 . století jednak se vznikem nových států (Prohlášení nezávislosti Spojených států amerických roku 1776), jednak jako doprovodný jev a důsledek revolučních změn (francouzská Deklarace práv člověka a občana roku 1789).

\section{Ius positivum vs. ius naturale}

$\mathrm{V}$ průběhu popsaného historického utváření konceptu lidských práv došlo v rámci tzv. právní- 
ho dualismu ke zrodu dvou základních teorií pozitivněprávní a prirozenoprávní, které významně ovlivnily další vývoj v této oblasti, pokud se týká zejména chápání původu lidských práv a jejich trvání. Pozitivněprávní teorie měla velkou odezvu a zastání zejména v 19. století a její zájem se soustředil na platné právo. Za právo uznávala v podstatě pouze právní normy, zákony člověkem vytvořené, a odmítala širší, metafyzickou podstatu práva. Z pohledu této teorie se chápání práva omezovalo na soubor právních norem platných $\mathrm{v}$ určitém státě. Naproti tomu přirozenoprávní teorie připouštěla (u principů pririrozeného práva ius naturale - stáli antičtí myslitelé, precizoval je výše zmíněný britský osvícenec John Locke), že vedle člověkem vytvořených norem (tedy vedle tzv. pozitivního práva - ius positivum) existují určitá práva a právní principy, které jsou na lidském konání a vưli nezávislé, protože se odvozují od samé „přirozenosti lidské“ a jako taková nemohou být žádným libovolným zásahem jednotlivců nebo státu zúžena či zrušena. Takto nahlíží na lidská základní práva a jejich původ i zmiňovaná Putz, podle níž se jedná o ,sumu nezcizitelných a nezadatelných práv, která od přírody př́sluši každému člověku na základě jeho existence, nezávisle na príslušnosti $\mathrm{k}$ určitému státu nebo určité skupině“. Za základní práva pokládá „ústavně zakotvená a tím soudně vymahatelná lidská práva. Jsou to stěžejní práva individuí vůči státu“ (Putz, 1992). Kovař́k k tomuto uvádí, že „stát tato práva uznává a chrání, nikoli propůjčuje. Ústava je pouze deklaruje, nikoli vytvář́c“ (Kovařík a kol.,2001). Nahlížení na lidská práva prizmatem prírozenoprávní teorie se prosadilo ve 20. století, zejména pak po druhé světové válce jako její důsledek, v podobě odporu demokratických států $\mathrm{k}$ masivnímu porušování lidských práv, rozpoutanému nacistickým Německem (Spolek Juristic, 2000). Je pochopitelné, jak uvádí Kovařík, že ,po hrůzách 2. světové války, po Osvětimi a po stalinských genocidách a Gulagu se západní svět k lidským právům s novou rozhodností vrátil, začal jejich koncept a formulace prohlubovat, rozvijet a především zakotvovat $\mathrm{v}$ dokumentech mezinárodní legislativy" (Kovařík a kol., 2001). A tak se, pod dojmem zločinů proti lidskosti spáchaných během války, přistoupilo $\mathrm{k}$ formalizované úpravě lidských práv na mezinárodní úrovni a následně i $\mathrm{k}$ jejich implementaci do pozitivního práva jednotlivých států. V České republice deklaruje pŕirozenoprávní charakter lidských práv Listina základních práv a svobod, která je dle čl. 3 a 112 Ústavy ČR součástí ústavního pořádku České republiky (MV ČR 1993).
Přísné rozlišování ve smyslu uvedeného právního dualismu však již v současnosti neobstojí, nebot' $v$ právních řádech většiny států jsou akceptované přirozenoprávní principy (lidská práva) zakotveny zpravidla v platném - pozitivním právu, a ostré hranice obou koncepcí jsou tudíž poněkud setřeny (Boguszak at al. ,2004).

\section{Definice a obsah lidských práv}

Jak již uvedeno, slovní spojení „lidská práva““ je spojením značně používaným, a to v nejrůznějších situacích a kontextech (často se používá párově s pojmem „svoboda“ či „základní svoboda“, kterou lze definovat jako možnost konat vše, co neškodí někomu jinému - tzn. nejedná se o absolutní, bezbřehou možnost libovolného konání, jak je někdy mylně chápáno, nýbrž je právě omezena stejnou možností konání danou ostatním jedincům a jimi v různém rozsahu využívanou (Pavlíček a kol., 2002). Definic „lidských práv“ je mnoho, $v$ následujících rádcích jsou nabídnuty ty nejdůležitější.

Z hlediska právní teorie jsou lidská práva subjektivními právy veřejné povahy, svědčícími vždy určitému subjektu, konkrétně živé lidské bytosti od jejího narození až do smrti(Boguszak J. et al. , 2004). Zde je třeba upozornit, že tyto hranice (zejména narození jako okamžik ,,vzniku“ nového subjektu podle tradičního chápánî) nejsou již dnes absolutně nepřekročitelné a některé dokumenty z oblasti lidských práv zmiňují práva i tzv. nascitura (nasciturus pro iam nato habetur). (HCJB World Radio) S konkrétními významnými právními důsledky (v právu rodinném, dědickém apod.) pro počaté, avšak ještě nenarozené dítě, pakliže se narodí živé, počítá např̀. i český občanský zákoník v ust. \ 7 (Jehlička et al., 1994) .

Lidská práva jsou také nároky lidí vůči státu, oprávněním jednotlivců požadovat od státu určité chování (Pavlíček a kol., 2002). Toto chování státu spočívá zejména $\mathrm{v}$ respektu, nezasahování do práv člověka (pasivní prvek) a jednak v jejich ochraně (aktivní prvek), hrozí-li jejich porušení, nebo takové porušení již nastalo.

Z pohledu filozofických úvah jsou lidská práva tím, co nám dovoluje plně rozvijet a využívat naše lidské kvality, naši inteligenci, schopnosti a vědomí a uspokojovat naše duchovní a jiné potřeby, ovšem pouze tehdy, jsou-li zachovávána. Jsou založena na rostoucím požadavku lidstva na život, ve kterém se základní důstojnosti a hodnotě každé lidské bytosti dostane respektu a ochrany (Nadace Naše dítě 2004). Ve svém souhrnu nejsou lidská práva ničím jiným než různými kvalitativními stránkami práva na život (Spolek Juristic, 2000). Dostálová k tomu doplňuje, že lidská 
práva lze definovat jako práva, bez nichž lidské bytí přestává být sebou samým (Dostálová, 1994). Kroupová dodává, že základní myšlenkou lidských práv je rovnost všech v jejich lidské důstojnosti: pro její dosažení člověk potřebuje svobodu, neoddělitelně svázanou s odpovědností, aby uplatňováním práv a svobod jednoho člověka nebyla dotčena či omezena svoboda a práva druhých (Kroupová, 1994).

Obsah pojmu „lidská práva“ tvoří mnoho jednotlivých, dílčích práv (viz následující oddíl), lišících se nejen dobou jejich vzniku či zakotvením v právních dokumentech, ale např. i intenzitou jejich ochrany, která je jim poskytována.

\section{Generace lidských práv}

Lze rozlišit tři základní kategorie (skupiny, generace) jednotlivých práv, která tvoří v souhrnu obsah práv lidských (Nadace Naše dítě 2004). $\mathrm{V}$ prvé řadě se jedná o tzv. negativní práva. Vyjadřují to, co společnost člověku dělat nemá, a jsou právy skutečně univerzálními, která by neměla záviset např. na ekonomických či kulturních podmínkách. ${ }^{20}$ Některá z nich mají charakter již zmíněných práv absolutních, nederogovatelných (tzv. základní práva). Aby mohla být negativní práva každého jedince naplněna, musí být zachováváno základní pravidlo - totiž že všechny ostatní subjekty splní svou povinnost do tohoto práva nezasahovat. Vyžaduje se tedy respekt od všech ostatních. $\mathrm{V}$ prípadě porušení práva dosahujícího určité stanovené intenzity, at' již ze strany jiného občana či státu, následuje trestní stíhání. Náleží sem zejména práva označovaná $\mathrm{v}$ různých právních dokumentech jako práva občanská, která mají vztah prímo $\mathrm{k}$ lidské bytosti jako takové a bez jejichž zachovávání bychom nemohli jako lidé vůbec existovat (právo na život, lidskou důstojnost, právo nebýt mučen, týrán či podroben jinému nelidskému a ponižujícímu zacházení, právo vlastnit majetek, právo na svobodu myšlení, pohybu, svědomí, právo na rovné zacházení apod.), a dále tzv. práva politická, která zaručují jedinci účast na veřejném životě (svoboda projevu, právo vyjadřovat své názory, právo petiční, shromažd’ovací, sdružovací apod.).

Druhá generace lidských práv zahrnuje tzv. práva pozitivní. Typově se jedná o práva relativní, to znamená právu jednoho subjektu odpovídá povinnost jiného konkrétního subjektu (tedy ne všech ostatních). Cílem jejich úpravy je ochránit sociální spravedlnost od zvůle a umožnit jedinci účast na sociálních, hospodářských a kulturních aspektech života. Základním pravidlem, které umožňuje naplnění pozitivních práv, je nutnost respektu subjektu povinného $\mathrm{k}$ právu subjektu oprávněného a dále poskytnutí ochrany tomuto právu ze strany státu (Nadace Naše dítě 20022004). Náleží sem práva označovaná v právních dokumentech souhrnně jako hospodářská, sociální a kulturní (nap̌r. právo na vzdělání, práci, spravedlivou mzdu, lékařskou pomoc $\mathrm{v}$ nemoci, sociální zabezpečení apod.). Zakotvení těchto práv v mezinárodních dokumentech (typicky Mezinárodní pakt o hospodářských, sociálních a kulturních právech) je však svým způsobem problematické. Jařab $\mathrm{k}$ tomu poznamenává: „... v pravicovém liberálním diskurzu zní silný názor, že tato práva do komplexu lidských práv nepatří. Jsou obtížně vymahatelná, obtížně kvalifikovatelná... Je nesmírně těžké až nemožné kvalifikovat, co je adekvátní bydlení, príměřená mzda, takže tato práva nelze vymáhat soudně. Řazení těchto pozitivních práv, která státu nic nezakazují, ale říkají, jak by něco mělo být, je podle pravicových liberálů bezzubé a dokonce škodlivé. Mají za to, že zahrnutím vágních práv dochází $\mathrm{k}$ jakési inflaci či rozmělnění celého pojmu lidských práv, která by se měla vztahovat jen na ta občanská a politickác“. (Reifová, 2004). Jařab tedy nepovažuje za nejšt'astnější myšlenku vyjadřovat hospodářská, sociální a kulturní práva ve formě dokumentů o lidských právech. $\mathrm{V}$ praktické rovině je podle jeho názoru užitečnější, když se zrodí konkrétní nápad či projekt, jak pozvednout např. hladinu vzdělanosti či vyřešit bytovou otázku, než když někomu jakákoliv soudní instance přizná, že na to má právo (Reifová, 2004). Joch k nárokovosti sociálních práv uvádí: „Problémem sociální koncepce práv je to, že je vágní... Co znamená právo na byt? Co je ještě bytem? Kdybychom za byt považovali jakýkoliv brloh či zemljanku, tak toto právo by bylo samozrejmě vtipem. Kdybychom považovali za byt superluxusní bydlení, tak vidíme, že toto právo je neudržitelné“. I on se tedy domnívá, že sociální práva nemohou být univerzální ( $\mathrm{k}$ tomu viz dále). Je to dáno především jejich ekonomickou podmíněností (Joch a ŽZeglitz, 1998). Je třeba doplnit, že se skutečně jedná o práva závisející velmi silně na ekonomické úrovni (obecné i aktuálnî) toho kterého státu, a ta bývá mnohdy i při sebelepší vůli vlády těžko ovlivnitelná.

Třetí generace práv zahrnuje tzv. práva kolektivní. Mají zajistit, obecně řečeno, právo každého na to, aby vládl takový společenský mezinárodní řád, ve kterém by základní lidská práva a svobody byly plně uskutečněny. Řadíme $\mathrm{k}$ nim např̀. právo na mír, právo na rozvoj, právo na společnou bezpečnost, právo na ekonomickou prosperitu, právo na čisté životní prostředí apod. Přesný výčet kolektivních lidských práv však neexistuje. Lauritzen 
k tomu uvádí, že při zrodu třetí generace práv hraje důležitý faktor zvyšující se role zemí tzv. třetího světa, nebot' tyto země požadují společnou bezpečnost, právo na kolektivní sebeurčení vlastních záležitostí. A „my zase chceme společnou ekonomickou prosperitu a společný mír". Navíc, „zcela nedávno nám také ekologický vývoj ukázal, že potřebujeme dojít $\mathrm{k}$ určitým společným dohodám na celosvětové úrovni, a to je právě tato třetí generace lidských práv“ (Lauritzen, 2001).

\section{Prameny lidských práv (a svobod)}

Pramenem (nejen) lidských práv rozumíme jejich zakotvení či vyjádření $\mathrm{v}$ určité formě. $\mathrm{K}$ bezesporu nejdůležitějším pramenům jakožto mezníkům na cestě vývoje lidských práv patří zejména „Habeas Corpus Act“ - anglický zákon na ochranu osobní svobody občanů z roku 1679 potvrzující ustanovení listiny Magna charta libertatum (1215), dále anglická Bill of Rights (Listina práv, 1689), Ústava Spojených států amerických (1787), francouzská „Deklarace práv člověka a občana“ (1789) nebo např. Deklarace práv dítěte z roku 1924. Bezprostředně po druhé světové válce nastal, $\mathrm{z}$ důvodů výše uvedených, zvýšený zájem o lidská práva a progresivní př́stup k této problematice. Byly položeny základy nového světového pořádku. Na konferenci v San Francisku byla v roce 1945 koncipována Charta jako zakládající dokument Organizace spojených národů (OSN). Její článek 1 výslovně stanoví, že k cílům OSN patři „podporování a posilování úcty k lidským právům a základním svobodám pro všechny bez rozdílu rasy, pohlaví, jazyka a náboženstvi“". Valné shromáždění OSN príijalo následně, v roce 1948, Všeobecnou deklaraci lidských práv, která se postupně stala nejvýznamnějším mezinárodním dokumentem $\mathrm{v}$ dané oblasti. Její zrod nebyl rozhodně jednoduchou záležitost, jen počet dílčích hlasování o konečné podobě textu přesáhl číslo 1400 (sic!). ${ }^{1}$ Ač není právně závazná (má pouze morální sílu), těší se mezi státy i světovou veřejností velkému respektu a prestiži jako málokterý jiný mezinárodní dokument, o čemž svědčí i fakt, že lidstvo si každoročně připomíná 10. prosinec, kdy Valné shromáždění OSN Deklaraci príijalo, vyhlásilo její obsah a následně vyzvalo všechny členské státy OSN, aby její znění zveřejnily a podpořily její šíření po celém světě, jako „Den lidských práv“. Organizace spojených národů se tak zavázala, a to již v Chartě, k podpoře, propagaci a ochraně lidských práv všech jednotlivců, vycházejíc z víry obyvatel světa $\mathrm{v}$ základní lidská práva a hodnoty člověka.

Deklarace zakotvila obecný standard v oblasti ochrany a respektování práv všech lidí a národů.
Právě z důvodu pouhé morální, nikoliv právní závaznosti deklarace, usilovala OSN o zakotvení základních lidských práv a svobod ve formě mezinárodních závazných smluv, které by se po prijietí a ratifikaci smluvními státy staly součástí jejich vnitřního zákonodárství. Tento proces byl úspěšně završen v roce 1966, kdy v prosinci Valné shromáždění přijalo Mezinárodní pakt o občanských a politických právech a již zmíněný Mezinárodní pakt o hospodářských, sociálních a kulturních právech. Oba pakty ratifikovala i tehdejší ČSR (zák. č. 120/1966 Sb.) a jsou tedy součástí právního řádu České republiky jako nástupnického státu. Mezi další významné dokumenty patř́ Úmluva proti mučení (1984), Úmluva o právech dítěte (1989), četné úmluvy Mezinárodní organizace práce atd.

Také na evropské úrovni byly mezitím přijaty významné dokumenty o lidských právech. Z nich je třeba zmínit alespoň Evropskou úmluvu o lidských právech, což je dokument Rady Evropy vyhlášený již v roce 1950 a platný mj. také v České republice, eventuálně úžeji zaměřenou Evropskou sociální chartu z roku 1961 (také dokument Rady Evropy; ČR ratifikovala až v roce 1999).

V rámci vnitrostátního práva České republiky představuje základní katalog práv a svobod zmíněná Listina základních práv a svobod.

Uvedené dokumenty tedy zakotvují taková lidská práva a svobody, jako je právo na život, osobní svobodu, nedotknutelnost osoby a soukromí, právo nebýt jakkoli diskriminován $\mathrm{z}$ důvodu pohlaví, rasy, barvy pleti, jazyka, víry, politického smýšlení, národního či sociálního původu, právo na zachování lidské cti a důstojnosti a na ochranu jména, právo svobodně se shromažd'ovat a sdružovat, právo projevovat své názory, právo na přiměřené zabezpečení v určitých nepř́iznivých situacích, právo na vzdělání, na zdravotní péči, na soudní ochranu, svobodu myšlení, svědomí a náboženského vyznání apod.

\section{Meze lidských práv}

Lidská práva mohou být omezena jen zcela výjimečně, pokud ohrožují či omezují podobná nebo srovnatelná práva jiných. Hýbnerová $\mathrm{k}$ tomuto poznamenává, že právě vymezení hranic lidských práv je jejich důležitým aspektem. Je totiž nesporné, že realizace práva a svobody jednoho člověka může vést $\mathrm{k}$ porušení práv a svobod jiných. Určitá práva lze za striktně stanovených podmínek, napřr. $\mathrm{v}$ prípadě války nebo jiného ohrožení existence národa, omezit či derogovat. To se ovšem netýká některých stěžejních (též „základních") lidských práv (odvozených od samé přirozenosti lidské - např. právo na život a lid- 
skou důstojnost, zákaz mučení, otroctví a retroaktivity trestních zákonů), kde se derogace nepřipouští za žádných okolností a tato práva se tak stávají právy absolutními (Hýbnerová, 1994). Základní lidská práva (a svobody) dle současného pojetí a chápání (a zmiňuje to i Listina základních práv a svobod ve své preambuli, když hovoří o „,neporušitelnosti přirozených lidských práv“) jsou „nezadatelná, nezcizitelná, nepromlčitelná a nezrušitelná" (čl. 1). To znamená, že nikdo se nemůže svých základních práv vzdát ve prospěch jiného ani jich být zbaven (např. zákonem) ani je nemůže na jiného platně převést. Základní lidská práva dále nepodléhají promlčení a nemohou být zrušena žádným způsobem, žádným předpisem jakékoliv právní síly ani většinovou vưlí lidu vyjádřenou nap̌r. v referendu (Pavlíček a kol., 2002) .

\section{Univerzalita lidských práv}

$\mathrm{S}$ ohledem na současný stupeň vývoje $\mathrm{v}$ dané oblasti lze jistě souhlasit $\mathrm{s}$ převažujícím míněním, že lidská práva jsou neodmyslitelná našemu (lidskému) prostředí (Nadace Naše dítě 20022004), že jsou právy univeráálními, vztahujícími se ke všem osobám bez jakékoli diskriminace, tj. náležející všem a všude bez rozdílu. Univerzálnost lidských práv je však výsledkem až recentního vývoje této oblasti, nebot' samozrrejmě platí, že existence člověka je mnohem delší a sahá mnohem dále do minulosti, než je tomu $\mathrm{v}$ př́padě vzniku lidských práv a jejich utvoření do té podoby, kterou známe dnes. Lidský rod se větší část svého trvání bez lidských práv obešel, než postupně došel k jejich poznání. Člověk jako lidská bytost by tedy bez lidských práv žít dokázal, nicméně za zcela jiných podmínek, které dávaly takovému životu zcela rozdílný obsah a kvalitu. V současných socioekonomických podmínkách a s ohledem na dosažený stupeň vývoje lidstva si však lze jen stěží představit, že by lidská práva obecně neexistovala, nebyla zakotvena a patřičným způsobem i chráněna. $\mathrm{Na}$ univerzalitě lidských práv je proto jistě možné se shodnout, zejména pokud se jedná o základní lidská práva, jejichž minimální standard je nastaven mnoha právními dokumenty. Je však třeba neustále zdůrazňovat, že právo se stává skutečným právem až tím, že je respektováno, prosazováno a chráněno (státním donucením). Jinak zůstává pouhou proklamací na papíre.

Ohledně univerzálnosti ostatních lidských práv (zejména ekonomických, sociálních) a rozsahu, $\mathrm{v}$ jakém mají být přiznána a chráněna, se však již názory různí. Např. Jařab v reakci na tvrzení, že pojem lidských práv je produktem Západu a že by mělo být pečlivě váženo, nakolik ho vnucovat jiným kulturám, uvádí: „Jako absolvent kulturní antropologie bych jistě měl směřovat ke kulturnímu relativismu, jako zastánce lidských práv $\mathrm{k}$ univerzalismu ... je to velká kontradikce, se kterou zápasí všichni západní obhájci lidských práv... Nejvíce cítím relativistickou povahu u pozitivních práv sociálních a hospodářských.“ (Reifová, 2004). Zde lze jistě souhlasit s tím, že u lidských práv tzv. druhé generace, ve stále značně ekonomicky, sociálně a kulturně diverzifikovaném světě, je prosazení jejich univerzální stejné úrovně nejen nereálné, ale také nežádoucí. Takové snahy (a je třeba říci, že jako příslušníci „západní civilizace“ se na nich podílíme též) se totiž až př́liš přibližují nedobrovolnému vnucování hodnot národům, které je nesdílejí, resp. je mají nastaveny zcela odlišně, a jsou tak snahami zakládajícími spíše konflikt než porozumění a sblížení.

\section{Ochrana a šíření lidských práv zůstává té- matem i pro 21. století}

$\mathrm{V}$ tomto roce si $\mathrm{v}$ podzimních dnech pripomeneme důležité výročí - 24. října („Den Spojených národư") uplyne 60 let od chvíle, kdy ratifikací Charty jako ustavujícího dokumentu vznikla Organizace spojených národů. Tak bylo vytvořeno společenství, které má $\mathrm{v}$ náplni (vedle řešení sporů mezi státy především smírnými prostředky, udržování bezpečnosti a míru ve světě, rozvíjení prátelských vztahů a spolupráce mezi státy) také prosazování, podporu a propagaci lidských práv a dohled nad jejich dodržováním.

Z doposud uvedeného je více než zřejmé, že problematika lidských práv je látkou rozsáhlou, jejíž vyčerpání zcela přesahuje možnosti rozsahu tohoto článku. Je třeba říci, a vzhledem $\mathrm{k}$ vývoji ve světě je to jasně zřetelné, že sféra lidských práv, jejich prosazování a ochrana je a bude tématem aktuálním, živým, sledovaným. I po více než padesáti letech od přijetí Všeobecné deklarace lidských práv a navzdory úvodnímu mottu patrně není na světě státu, který by z hodnocení stavu a dodržování lidských práv vyšel se zcela čistým štítem. Problémy v podobě větších či menších prohřešků by jistě bylo možné nalézt všude, o flagrantním porušování práv některými státy vưbec nemluvě (např. zmiňované ozbrojené konflikty, autoritativní režimy apod.).

Pokud jde o Českou republiku a stav lidských práv, konstatuje se $\mathrm{v}$ závěru každoroční pravidelné Zprávy Rady vlády ČR pro lidská práva, že zejména $\mathrm{v}$ oblasti práv oslabených či ohrožených skupin nedosahuje ČR kvality většiny dosavadních členských zemí EU. Další problém představuje 
podle Zprávy přístup k otázce občanství. Stálou pozornost je třeba věnovat i oblasti azylové politiky, ochraně osobních dat, zásahům do občanských práv v souvislosti s bojem proti terorismu apod. (Rada vlády ČR pro lidská práva 2004)

Lze shrnout, že sladění pragmatických hledisek a potřeb, které se objevují $\mathrm{v}$ souvislosti s aktuálním mezinárodním vývojem, s požadavky lidských práv (např. zmiňovaný boj proti terorismu vs. požadavek na respektování lidských práv), je nelehkým úkolem, s nímž se vypořádává $\mathrm{a} \mathrm{v}$ budoucnu bude muset vypořádávat většina států, které se nazývají demokratickými.

\section{LITERATURA}

Amnesty International. Průvodce po stopách lidských práv [online]. Poslední aktualizace: 12.11.2003 [cit. 2004-06-21]. Dostupné z: <http://www.amnesty.cz/pruvodce/ podstata.php>.

Boguszak, J. et al. 2004: Teorie práva. Praha, Aspi Publishing, 347 s. ISBN 80-7357-030-0.

Coreth, E. - Schöndorf, H. 2002: Filozofie 17. a 18. století. Přel. D. Milk. Olomouc, Nakladatelství Olomouc, 310 s. ISBN 80-7182-105-5.

Dostálová, R. 1994: Vyučování lidským právům. In: Rozumíme lidským právům? Praha, Evropské informační středisko Univerzity Karlovy, s. 76-79. ISBN 80-90-1221-4-0.

HCJB World Radio. Deklarace práv počatého dítěte [online]. Poslední aktualizace: 28.1.2004 [cit. 2004-06-22]. Dostupné z: <http:// www.hcjb.cz//Zapas_o_dusi/65/

zodc6508.phtml>.

Heinzmann, R. 2002: Středověká filozofie. Přel. B. Horyna. Olomouc, Nakladatelství Olomouc, 351 s. ISBN 80-7182-105-5.

Hejč, K.: Sociální aspekty lidských práv. České Budějovice, Jihočeská univerzita v Českých Budějovicích, Zdravotně sociální fakulta, teze přednášek Akademický rok 2002/2003.

Hýbnerová, S. 1994: Mezinárodní ochrana lidských práv. In: Rozumíme lidským právům? Praha, Evropské informační středisko Univerzity Karlovy, s. 29-53. ISBN 80-90-1221-4-0.
Jehlička, O. - Švestka, J. et al. 1994: Občanský zákoník - komentář. 6. vyd., Praha, C.H.Beck, 1448 s. ISBN 80-7179-339-6.

Joch, R., Žeglitz, J. 1998: Přerozdělování bohatství [online]. 5. veřejné slyšení občanského sdružení Archa. Praha, [cit. 2004-06-22]. Dostupné z: <http://www.ceft.cz/ prirozena_prava.htm>.

Kovařík, J. a kol. 2001: Dětská práva, právní povědomí, participace dětí a sociální služby. České Budějovice, Jihočeská univerzita v Českých Budějovicích, Zdravotně sociální fakulta, 222 s. ISBN80-7040-531-7.

Kroupová, A. 1994: Úvod do výchovy k lidským právům. In: Rozumíme lidským právům, Praha, Evropské informační středisko Univerzity Karlovy, s.14-28. ISBN 80-90-1221-4-0.

Lauritzen, P. 2001: Úvodní řeč Studentského fóra 2000 [online]. In: Sedmá generace. Praha, Hnutí Duha, [cit. 2004-06-23], roč. 2001, č. 8. Dostupné z: <http://www.sedmagenerace.cz/ sg97_01/2001/8lauritz.htm>.

Ministerstvo vnitra ČR 1993: Sbírka zákonů ČR, Usnesení ČNR č. 2/1993 Sb. - Listina základních práv a svobod, Praha.

Nadace Naše dítě 2002-2004: Lidská práva definice lidských práv [online]. Praha.[cit. 2004-06 -24]. Dostupné z:<http://www.destskaprava.cz/ pedagog/opravech_prava.asp>.

Pavlíček, V. a kol. 2002: Ústava a ústavní řád České republiky - komentár. Praha, Linde, 1164 s. ISBN 80-7201-391-2.

Přibáň, J. 1996: Sociologie práva. Praha, Sociologické nakladatelství, 199 s. ISBN 80-85850-18-4.

Putz, G. 1992: Christentum und Menschenrechte. 3. vyd. Innsbruck, Wien, Tyrolia-Verlag, $449 \mathrm{~s}$.

Rada vlády ČR pro lidská práva 2004: Zpráva o stavu lidských práv v České republice v roce 2003. Praha. [cit. 2004-06-28]. Dostupné z: <http://wtd.vláda.cz/urad_postaveni.htm>.

Reifová, I. 2004: Praktický humanismus Jana Jařaba [online]. Praha. [cit. 2004-06-21]. Dostupné z: <http://www.rozhlas.cz/cro6/pritomnost/ zprava/52325>.

Spolek JURISTIC. Pojem lidských práv [online]. In: Český právnický publikační a informační 